\title{
(Mis)-understanding Nation and Identity: Re-imagining Sport in the Future of African Development
}

\author{
Fibian Kavulani Lukalo*
}

\begin{abstract}
Athletics, its obsession and allure for economic empowerment (marathons, World Championships, Golden League track events) through skill and will, unlike any other sport in Kenya, has generated contestations in the emergence of national identity. Thus the crisis in the body Athletics Kenya (AK), the Ministry for Gender, Sports and Culture and among individual athletes in Kenya today is symbolic of the crisis of individuality, nationhood and identity in African development. Since the 'defection' of Wilson Kipketer in 1998, Kenyan athletes have negotiated and have 'run' for citizenship in the Middle East, Europe and the United States. At stake is whether athletes, athletics, sports policy and the governing bodies are witnessing an evolution or devolution in autonomy especially when citizenship changes necessitate identity changes as is the case of the Qatar/Bahrain 'defecting' athletes. The paper presents the case for this issue, while situating the practise of athletes 'defecting' within the global flows of movement and questions of identity.
\end{abstract}

\section{Résumé}

Lathlétisme, et son obsession et son attrait envers l'ascendance économique (marathons, championnats du monde, épreuves sur piste de la Golden League) grâce au talent et à la volonté a généré des contestations dans l'émergence d'une identité nationale, plus qu'aucun autre sport au Kenya. Ainsi, la crise au niveau de Athletics Kenya (AK), l'organisme kenyan responsable de la gestion de l'athlétisme, du Ministère du Genre, des Sports et de la Culture et des athlètes individuels au Kenya, aujourd'hui, est symbolique de la crise d'individua-

* Moi University, School for Human Resource Development, PO Box 3900-30100,

Eldoret, Kenya. Email: fkavu@yahoo.com 
lité, de statut national et d'identité en matière de développement africain. Depuis 1998 et la « défection » de Wiilson Kipketer, les athlètes Kenyans ont négocié et « courue » à la recherche de citoyenneté au Moyen-Orient, en Europe et aux Etats-Unis. La question en jeu consiste à voir si les athlètes, l'athlétisme, la politique sportive et les autorités gouvernantes sont en proie à une évolution ou un transfert d'autorité, particulièrement dans un contexte où le changement de citoyenneté s'accompagne de changement d'identité, comme ce fut le cas des athlètes qui ont migré au Qatar/Bahrain. Cet article présente ce cas de figure, tout en situant cette pratique des athlètes « migrants » dans le contexte des flux mondiaux et des questions identitaires.

\section{Introduction}

The African continent today has reached a definitive moment in the nurturing and provision of talent in sports globally. Since 1968 in Kenya, every time the Olympics games are held, the track athletics events become national moments for symbolic dissemination of power and in particular portray the socio-economic dimensions of emerging symbols in the globalised arena of sport. Subject to external interventions and influences, track athletics has enmeshed itself firmly within the global capitalist system. Part of this spread of capitalist consumerism in athletics is found in international meetings such as the Olympics and the Commonwealth Games. Athletics agents are all located in Western capitals. The crisis in Athletics Kenya (AK), the Ministry for Gender, Sports and Culture and among individual athletes in Kenya today is symbolic of the crisis of individuality, nationhood and identity in African development. The athletics track has been transformed from a space defined as equal, offering sovereign rights to the competing athletes, to one where individually athletes echo and shoulder the contested symbol of nationalism in the 'running for money or petrol dollar' debate. Publicly an individual athlete's ability is subsumed into a political collectivity for the purposes of nation building where the successful body performs and promises the triumph of the body politic. The track, however, collapses the separation between the athletes and the Kenyan spectators in a moment where athletic events have historically embodied the Kenyan nation and its narrative of triumph.

In essence, the growth of athletics in Kenya is variously situated in the discourse of the development of the nation. For instance, track athletics, starting from the 800 metre race, describes the history of the nation by constituting athletics as a potential subject for the national epic. However, the contemporary market-oriented glamour of global 
sports influences athletes' patterns of training and allegiance to the ideals of nationalism and identity. The example of Kenyan-born, Danish citizen, Wilson Kipketer, was a starting point to critically evaluate the discourses of nationalism, identity and culture in the development of sports as an economic alternative in Kenya. Were these issues envisaged in the developmental agenda for Kenya or Africa? Since Kipketer's 'defection', Kenyan athletes have negotiated and have 'run' for citizenship in the Middle East, Europe and the United States. At stake is whether athletes, athletics, sports policy and the governing bodies are witnessing an evolution or devolution in autonomy especially when citizenship changes necessitate identity changes as is the case of the Qatar/Bahrain 'defecting' athletes. The image and perception of the athlete in Kenya today publicly pronounces the hidden relations of consumerism, and power and generally illuminates global trends of modernity and the contradictory economic predicaments Africans face today. Athletics, its obsession and allure for economic empowerment (marathons, World Championships, Golden League track events) through skill and will, unlike any other sport in Kenya, has generated contestations in the emergence of national identity. Other issues that inform this trend but are beyond the confines of this presentation include political developments and athletics, athletics and its administration over time, athletics once as a preserve of the Rift Valley and now open to all Kenyan competitors, the gendered dynamics of athletics, history and athletics, and the rise of athletic personalities. At the present time, there is a disjunction between ideals of nationhood, identity, culture and individual pursuits in athletics. As such, (re)writing nationhood and identity through athletics invites analysis of the contemporary phenomenon of socio-economic development in Kenya. Athletics as a sport offers a platform from which to further develop an investigation of the contingent relation of the many discontents associated with the current phase of globalisation and the necessity for Africa and individuals to regain the policy initiative. Using recent media reports of the transformed Middle East 'Qatar/Bahrain defectors', the paper examines the ways in which global forces have impacted on the nation, on the culture of athletics as it relates to the debate and the crisis of nationhood and identity in seeking to create a space for Africa-centred development. 


\section{Reilections on Individuals, Nationhood and Identity}

Last Saturday, 21 -year-old Kimutai Kigen walked into the Nation Centre with a peculiar request: 'How can I go to Qatar? I am desperate', he said. 'The Military is not recruiting. No club is willing to take me in and I have to survive. The government should assist us go to Qatar, Bahrain or any other country'. ${ }^{1}$

Globalisation and the need for economic migration constitute an unstoppable force in today's world. However, the key role of actors like Kigen in creating and further shaping the globalisation process is important. As an individual, Kigen's quest (un)consciously can be seen to influence the dynamics and varying contexts of the direction which globalisation takes. The relevance of Kigen's request emphasises the multiple level of dominance and the centrality of athletics in Kenya's developmental agenda and history of sports. Furthermore, it augments the impression that the globalisation of economic and communication systems has enabled and motivated Kenyans to seek economic transnational migration. Central to this claim is a younger generation born into the global experience and who seem to have a less salient attachment to patriotism. By seeking and adopting cosmopolitan lifestyles and global political identities, individuals see the government as being less supportive in addressing their personal, social and economic needs (Castells 1996). ${ }^{2}$ In this perspective the grounds are laid by individuals like Kigen for an identity shift, detached from the activities of traditional citizenship. These athletes instead are ready to embrace fluid global identities and defiant stances in their quest for economic emancipation. Consequently, the political power of the individual becomes organised around the social networks of the self. Kigen's quest for migration is not a new phenomenon, given that many Kenyans dot the globe.

However, the phenomenon today poses a challenge to national identities and the 'preserve' of social and economic spaces with new patterns of solidarities emerging. Athletics as a sport has been re-ordered and developed, with the opening up of high altitude training camps, and multinational sponsorship events in Kenya like the annual Nairobi Marathon and the pastoral communities' marathon. In these endeavours capitalism provides a basis for profits as well as identities that sustain hegemony and the ideological control of sports culture to produce individuals willing to consent to the new economic reality. The view of Kosgei below depicts the re-organisation of sport in accordance 
with dominant world-cultural models and market forces engendering increasing individualism. It also becomes clear that experiences in the local and global processes through which they are acquired and imbued with value play a big part in altering the perspective about the world beyond them and their place in it. Therefore, athletics as an experience with its images and ideas impacts on identities and will continue to play a major role in the ideology and practice of athletics. The contested identities and the local contexts under which they are constructed or modified are often heavily influenced by global forces. Therefore athletics in Kenya has become a critical arena for contestation.

'Athletics is threatened in this country. With athletes like Kemboi and Langat going, I can't imagine what the situation will be like in the next 10 years. It is very alarming,' said former national head coach, Mike Kosgei. ${ }^{3}$

The transnational movement of athletes like Langat, decried by Kosgei, potentially influences the diasporic and world view towards the defection of athletes and the view of sport as an economic enterprise in general. For example, Langat's decision to change his citizenship and become a US citizen was influenced by his training and family commitments. Similar sentiments have been expressed by Wilson Kipketer and Lorna Kiplagat. Therefore changes in citizenship depend on individual contexts selectively appropriated and modified. There is also a group of athletes like Paul Tergat, Tecla Lorupe and Catherine Ndereba who have expressed their intention of retaining their Kenyan citizenship. As such, the impacts of globalisation on the individual are viewed subjectively and in turn influence the construction of identity and political dynamics of sports. In this debate athletics takes on a pivotal position not only because of its intrinsic significance, but because it has become bound up in the fundamental question of identity and its many dimensions: personal, ethnic, religious, social and national.

Two former world champions, Ismael Kirui and Moses Tanui, argued that Kenyan runners lacked enthusiasm in the races in which they participated. Kirui, the 5000 metres world champion in 1993 and 1995, said: 'Either our runners lacked pre-race plans or there exists rivalry among them driven by selfishness'. ${ }^{4}$

This controversy brings to light a deeper form of alienation. Historically, the narrative of athletics in Kenya and the accompanying glamour has been shrouded by issues such as issues of disadvantages in education, the marginalisation of communities providing athletes, and the 
exclusion of athletics from the national debate until the Olympics. The trend started by Cherono and his fellow defectors challenges this narrative of marginalisation by swapping identity for recognition. At the award podium they also swap a familiar anthem symbolic of their national allegiance for one that signifies change and their rupture with normality in the global competitive arena. As individual runners they may have less power for negotiation but the lucrative deals provide them with more choices and a better lifestyle. The impact of this struggle for recognition by individuals produces varying reactions from the governments and other interested stakeholders.

The Ethiopian's great run reminded Ondieki ${ }^{5}$ of a similar breed of Kenyans which is now history ... Ondieki thinks the last of the great Kenyans are those who ran up to 1994, notably William Sigei, twice world cross-country champion ... Ondieki said the lack of education and focus are the major drawbacks facing athletes ... 'The federation was bad in our days but that did not stop us from winning championships and breaking records' ... He said Bekele would not be heard of until next year while Kenyans make newspaper headlines only to succumb in Bekele's presence ... 'We have become Grand Prix winners, non-record breakers and championship losers ... Kenyans are part of the circus that is the Grand Prix series and are like orphans at championships when they are on their own ... today's athlete is everywhere as if the world is coming to an end'. ${ }^{6}$

The process of identity creation and the emergent images as defined by ethnicity, race, religion, regional or national affiliations are historically contingent and socially contested. Rivalry between the Ethiopians, Moroccans and Kenyans for dominance in the track events provides an avenue to interrogate the myriad ways in which sports affects our identities.

\section{Power and Cartels of Seduction}

The Qatari defections began when William Tanui, the local contact person for KIM International Management group, was approached by a club in Doha to recruit two athletes. He then identified Stephen Cherono (world junior steeplechase champion in 2001) and Albert Chepkurui (fourth in the senior men's World Cross-Country 4000 metres in 2001). What Tanui had not foreseen in these early negotiations were issues like a change of citizenship and of names which the two athletes later discussed as part of their individual defection packages in 2003. Thus, until he got his Qatari passport in 2003, Cherono kept his 'defec- 
tion' plans secret. When Cherono running as 'Shaheen' beat the Kenyan champion Ezekiel Kemboi at the 2003 World Championships in Paris, the Kenyan government reacted with great anger and a probe committee was constituted to investigate the 'defection'. The role of Athletics Kenya in the defection saga was not without suspicion, since government policy and Athletics Kenya (AK) and IAAF rules were not evidently followed prior to the defections. Underhand deals must have been involved in these cases of defection, the concerned Minister said. 'AK should have a mechanism of producing more athletes to replace those that go to represent other countries'. ${ }^{7}$ Quoted in the foregoing article was the fact that over forty Kenyan athletes had at the time 'trafficked' to Qatar and Bahrain under unclear circumstances. So, as the consciousness begins to grow in Kenya that athletes' numbers exceed the demands of the sport and can be 'exported to buy citizenship', identity is subsumed and becomes part of an emerging narrative in sports.

In Kenya he was known as Moses Chirchir, a resident of Marakwet, which has produced the largest number of world-class steeplechasers. In the Athens Olympics, he was Al Badri Salem Amer ... The exodus of Kenyan athletes to the Gulf States, which started with the controversial defection of Stephen Cherono and Albert Chepkurui, aka Seif Saeed Shaheen and Hassan Abdallah is alarming ... more worrying is the constant flow of athletes from Eldoret, Iten and Central Kenya to Qatar and Bahrain ... two have gone to Saudi Arabia ... Kosgei ... is Saudi Arabian renamed Al Salhi Mohammed ... Qatar's Ali Thamer Kamel ... was Thomas Kosgei ... Rasheed Essa Ismael ... was Daniel Kipkosgei ... Salem Jamal was Thomas Katui. Others who have quietly defected recently to Bahrain are Isaac Waweru, now Abadeen Eshaaq, John Yego, now Ali Belal Mansour, Bekhait Saleh formerly Simon Mbuthia, Hosea Kipkemboi, Khamees Adam. Denis Sang, Taher Tariq, James Yatich, Faraj Shaheen, Peter Ndegwa ... Khalid Kamal Khalid ... David Nyaga ... Bashir Daham Najim. ${ }^{8}$

Though unsubstantiated it seems plausible that these two Middle East countries are engaged in complex underhand deals with some officials of AK, especially since the matter of citizenship seems riddled with uncertainty. One earlier case was that of the footballer Dennis Oliech (Al Arabi football club in Doha) who turned down a monetary offer to change his citizenship to Qatari. In Oliech's case his mother was quite categorical about the price of citizenship given a name change. Consumerism in the sense of more personalised, less collective public policy 
choices seems to be driving the core of the relationships between citizens and the government in the politics of sports.

Kenyans should forget the multi-million stadium that was supposed to be built at Kiplombe in Eldoret by the Qatari government ... the deal had everything to do with Kenya's Qatar-base footballer Dennis Oliech and not Saif Saeed Shaheen ... only if Oliech defected to Qatar prior to the last African Cup of Nations. ${ }^{9}$

The story of AK when viewed against the tide of defectors sounds like a tired soliloquy, since many of the officials have dominated the organisation for decades. The defectors act as both cultural citizens while at the same time claiming the right to remain in the new society (Turner 1993; Stevenson 1997). ${ }^{10}$ Training in Qatar due to its flatness is out of the question for all the athletes. Consequently, apart from Kenya, the Qatar government has established training camps in Morocco, South Africa, Brazil and the United States. The emergence of corporate sponsorship of events that honour athletes is part of the dissatisfaction of the Kenyan public towards the administration of AK. Some of the AK officials have gone to great lengths to defend the question of 'defection' in athletics unlike a similar instance when the footballer Oliech was asked to defect. This had drawn attention to the fact that relevant policies and frameworks for 'defection' need to be put in place. And one athlete who is being touted to take over the mantle of administrative leadership within AK is Paul Tergat, perhaps to make a success of his tenure like athletes such as Sebastian Coe of Britain who have managed sports.

'He was paid about $\$ 250,000$ (Kshs $19 \mathrm{~m}$ ). But the incentives are alluring. A World or Olympics gold is worth $\$ 100,000$ (Kshs 7.6m). The figures depend on which medals are won', ... 'Cherono is paid \$5,000(Kshs $380,000)$ per month, Kemboi about $\$ 2,000$ (Kshs 152,000). Recent recruits are being paid $\$ 1,000$ (Kshs 76,000) per month', ... Being paid for life is debatable. I doubt whether the Qataris or Bahrainis will give a damn about them after their active running days', he said, adding: 'This is why I opposed this venture from the start'. ${ }^{11}$

The above sentiments deal with athletic ability that is reduced by a capitalistic system to a commodity, which is only understood in terms of its monetary value and not intrinsic worth and meaning. And herein contained is the question of citizenship and name change. However, in an interview Cherono (Shaheen), gave some of his reasons for defection: the competitive environment for any athlete to make it onto the national 
squad; few opportunities available for a career; training costs left to the athlete.

[Shaheen's mother] was not happy with her son's change of allegiance. But there was little she could do. On the contrary, Shaheen's father Augustine Cherono, an athlete in his youth who chose to marry and start a family early, unlike his training mate Kipchoge Keino, embraced the idea wholeheartedly. In his youth athletics prices came in the form of lanterns, blankets and hoes. 'Not like today when one can live on running', 'I don't care what they call him', he told us. 'He went to secure his future and that is what we all want all young men to do. To me he is still Stephen and when he visits me he will always bring me something. ${ }^{12}$

Cherono's (Shaheen) defection to Qatar generated controversy principally due to the change in citizenship, the manner in which AK continued to handle the affairs of other younger athletes and the value of the steeplechase. In his 'defection' Shaheen provides for the individual voice, and the political signal he conveyed was one of defiance. Athletics seen as a symbol for unity and nationalism of Kenyans is weakened and portrayed as a sign of resistance. The cultural significance and value of the 3,000 metres steeplechase event in the history of Kenyan athletics is challenged whenever Shaheen wins the event and aligns himself with Qatar symbolically, living out the economic benefits. The steeplechase - a dominant preserve of Kenya - is now threatened with a contested identity shift; whereas the winner is Kenyan the anthem played is Qatari. The symbolic value and meanings the athletes and the nation have attributed to specific races is important in understanding the process of identity (Nyamnjoh 2001). ${ }^{13}$ The subjectivity given to the image of athletics enhances a wider understanding of the issue as an important mechanism for local and global interaction.

Currently thirty percent of the top marathoners in the IAAF rankings are Kenyans. Almost every week a Kenyan runner wins a marathon somewhere in the world ... the marathon is by far Kenya's strongest event, yet quality performances have been elusive in championship events ... as much as the world championships were well paying, there was no appearance fee. ${ }^{14}$

The hidden terrain of the sport in Kenya reveals underlying ethnic tensions and the game of football overtly depicts the ethnic image. But the fact that athletics will continue to contribute to the Kenya economy cannot be disputed. From its early beginnings in the 1960s, these ethnic dimensions were in evidence until the 1990s with the dominance of 
athletes from the Rift Valley-Kalenjin community. This scene was punctuated by athletes from the Kisii Highland region, and increasingly in the 1990s the emergence of athletes from Central Kenya. Predominantly, the athletics stable was created by the Armed Forces and it took effort from individuals like Brother Colm O'Connell to develop St Patrick's Secondary School in Keiyo-Marakwet District as a competitive 'search engine' for aspiring athletes. It was here that Cherono (Shaheen - The falcon of Qatar that will soar), began his running career. With the setting up of Qatari 'defectors' training camp in Iten town, an ethnic twist has been added to the debate. The Immigration Minister belongs to the Kalenjin ethnic group and is the Member of Parliament for Marakwet. Why is it that all defecting athletes are from one region? How do these young athletes get their documents processed without authorisation from AK? Who is involved in the negotiations and what are the longterm benefits to the athlete? Responding to some of these questions, below:

The International Association of Athletics Federations (IAAF), President Lamine Diack, yesterday asked countries affected by defections to provide incentives for their athletes ... a new rule says no runner can compete under new citizenship until after three years of acquiring it ... Kenya is the hardest hit by defections ... 'It's hard for a starving family to stop their son or daughter from going for US\$100,000 (Sh 7.6m) if they defect'. ${ }^{15}$

Yet, the fact remains that athletics in Kenya is controlled by a group of foreign coaches and investors who decide the training programme for the athletes. The role of AK in harmonising all the various facets of athletics has been wanting. Also it becomes imperative that upcoming disadvantaged athletes use successful athletes like Paul Tergat and Tecla Lorupe to inform their knowledge gap especially as far as training programmes and investments are concerned. Two Kenyans during the World Youth Championships in Marrakesh, Morocco in July 2005 falsified their ages to participate in the events. The two, Dennis Kipkurui Keter (Taker Tareq Mubarak) and John Yego (Ali Belal Mansoor) were overage for the events. The falsifying of ages was attributed to avarice from their Moroccan coach. 'He knows that by using these runners, they can win medals, and this will no doubt build his profile as a coach'. ${ }^{16}$

To avoid the controversy that surrounded Cherono's and Chepkurui's defections, the Italian coach has turned to young runners or those who have not represented Kenya internationally. 
'He is the one recruiting athletes for the Gulf States in Kenya. They have their base in Iten where they stay at Kerio View Hotel' ... 'He has made contacts with young villagers through established runners in his stable. They have rented houses in Iten and his movements in the villages is easy. ${ }^{17}$

The Kerio hotel charges Kshs 4,500 per night (approximately \$71), thus at the regional level providing much-needed business. The activities of these coaches need to be understood and examined, given the fact that some training camps are managed under deplorable conditions. Furthermore, in this era of all forms of illicit activities, it is imperative for the local authorities to undertake the mandate of overseeing the activities of these coaches. Sentiments expressed by observers like those below need to be given more scrutiny:

He enters Kenya on a tourist visa, which does not allow him to engage in gainful employment. Yet, he coaches and recruits athletes. He has now set up a training camp in Iten being funded by Qatari's, ... He requires a work permit endorsed by Athletics Kenya and Kenya National Sports Council to engage in what he has been doing in Iten ... he does not only contravene Kenya's immigration rules with impunity, but is also depleting Kenya's athletics talent ... The Italian coach has disdain for Kenyan athletes whom he variously refers to in unflattering terms. ${ }^{18}$

\section{Conclusion}

Movement in sport for African governments presents an opportunity to start a new phase of development and surveillance using approaches that are suited to the sport and the country's circumstances. Possibilities exist for the Kenyan government to provide guidance and a framework of operation for its athletes who wish to 'defect' for more lucrative deals. The debate will be lost if the governments concerned agree to be manipulated by promises that do not materialise, while the moral value of defection is ignored. If more Kenyans take up the 'defection' offer, should the government deter them? Or should it aid in this process? We should enable AK to be more responsive to the needs of athletes in Kenya, and also build on the success of Shaheen to uplift the standard of training in Kenya. With the high altitude training camp in Iten many Kenyans can make use of the facility and it presents an important investment incentive for those athletes who remain home to train. At the individual level 'athletics defectors' exist as transnational citizens, who continue to maintain strong links with home. They are able to develop 
adaptive complex, efficient systems to help them meet their training, communication and technological needs and in turn develop the infrastructure of rural areas like Iten and towns like Eldoret. The implications of the actions of 'defectors' by way of remittances channelled via banks or Western Union to the development of Africa is yet to be fully comprehended. Despite the question of name change and identity, the Kenyan government should mobilise this group of runners by using some form of coercive measures to ensure that they invest in Kenya and therefore are an important resource.

The number of Kenyans heading abroad is worrying the athletics world. 'From a moral point of view, we should avoid this transfer market in athletics. What we don't like is athletes being lured by large incentives by other countries and giving them passports when they arrive at the airport', commented Jacques Rogge, International Olympic Committee President. ${ }^{19}$

\section{Notes}

1. Special report in the Daily Nation, 1 June 2005, pp. 38-39, Njenga Peter and Macharia David, titled 'Powerful Gulf Cartel behind the Defection of Kenyan Track Stars'.

2. See Castells, Manuel, 1996, The Rise of the Network Society. Oxford: Blackwell.

3. Article from The Standard, 9 May 2005, p. 39, by Okoth Omulo, titled, 'Kemboi Defects to Qatar, to Run for Gulf State in Helsinki Global Tourney'.

4. Interview in the Daily Nation, 17 August 2005, p. 50, by Macharia David and Ouma Stephen.

5. Ondieki Yobes is one of the international athletes that Kenya has developed, running the 10,000 metres under 27 minutes in 1993. Other notable athletes over time, Ondieki notes, are Chelimo Richard, Rono Henry, Ereng Paul, Konchellah Billy, Ngugi John and Sigei William.

6. Interview with Ondieki Yobes in the Sunday Nation, 28 August 2005, p. 38, by Peter Njenga in Eldoret.

7. The Standard, 9 May 2005, p. 39, by Okoth Omulo, 'Two Officials Manipulated Rules to Push for Qatar Deal'.

8. Article by Okoth Omulo, in The Standard, 30 May 2005, p. 34, titled 'Many Young Kenyans are Heading to Gulf States'.

9. Sports article on the Qatari defections in The Standard, August 13, 2005, p. 25, titled 'Planned Stadium no More', by Mbaisi Chris.

10. Turner, B., 1993, 'Contemporary Problems in the Theory of Citizenship', in Turner, ed., Citizenship and Social Theory, London: Sage; Stevenson, N., 1997, 'Globalization, National Cultures and Cultural Citizenship', The Sociological Quarterly, 38: 41-66. 
11. Article by Okoth Omulo in The Standard, 30 May 2005, p, 35, titled 'Exodus to Qatar Intensifies'.

12. Special report in the Daily Nation, 1 June 2005, pp. 38-39, by Njenga Peter and Macharia David, titled 'Powerful Gulf Cartel behind the Defection of Kenyan Track Stars'.

13. See, Nyamnjoh, F. B., 2001, 'Concluding Reflections on Beyond Identities: Rethinking Power in Africa', in Identity and Beyond Thinking Africanicity, Discussion Paper 12, Uppsala: Nordiska Afrikainstitutet, pp. 25-33.

14. The Standard, 15 August 2005, p. 35, 'Kenyans Blame Course for Poor Show'.

15. Article by Mbaisi Chris in The Standard, 13 August 2005, p. 25, titled 'Good Incentives for Athletes will Cut Down on Defections, States Diack'.

16. Article by Mbaisi Chris in The Standard, 26 July 2005, p. 30, titled 'Ex-Kenyan Stars Face IAAF Probe'.

17. Ibid.

18. Article by Okoth Omulo in The Standard, 30 May 2005, p. 35, titled 'Exodus to Qatar Intensifies'.

19. Ibid. 
